\title{
THE FORMATION OF THE MAINTENANCE PROGRAM AND \\ ITS IMPACT ON THE INCREASED LEVEL OF POWER PLANTS RELIABILITY
}

\author{
Živoslav Adamović, ${ }^{1}$ Mladen Ivić, ${ }^{2}$ Veljko Vuković ${ }^{3}$ \\ ${ }^{1}$ Faculty of Applied Sciences Niš, Serbia \\ ${ }^{2,3}$ University PIM, Banja Luka, Republic of Srpska, Bosnia and Herzegovina \\ zivoslav.adamovic@gmail.com, ivic.mm81@gmail.com, v.velja@gmail.com
}

\begin{abstract}
The paper emphasizes the basic attitudes of complex technical system maintenance programming. Particularly it is performed an analysis and a selection of strategies for conditionbased maintenance. The assessment of the established maintenance program varieties effectiveness was carried out by comparison with their basic indicators of effectiveness (for corrective and preventive maintenance).
\end{abstract}

Keywords: programming, maintenance, maintenance program, power plant.

\section{Introduction}

The disadvantages of policies and strategies for preventive maintenance, in the broad areas of practice in recent years, initiated a trend of a maintenance planning based on its state system the process of exploitation (condition-based maintenance).

The basic advantages of maintaining towards state lie mainly in the reduction of maintenance costs (direct and indirect) and reducing the likelihood of delays in production, but can be achieved other positive effects, such as:

- ensuring the production of goods in the required quantities and within the prescribed quality.
Original Scientific Paper 10.5937/jouproman8-28553
- the safety increase of operating personnel (operators and on maintenance)

- reducing the waste of energy and of raw materials for the production and provision of labor component parts and or system in the regime of the highest efficiency,

- greater employee satisfaction, especially in the production and maintenance departments and others.

Preventive maintenance policy based on the execution of planned activities at certain intervals, regardless of the component parts technical condition and or the system, does not provide enough action and the link between changes in the technical conditions and process of exploitation.

Close relationship between them, by planning of works and the periodicity of their execution, depending on the technical condition and or the system obtained on the basis of diagnosis, is provided by the condition-based maintenance strategy.

Technical relationship provides the possibility of applying a large number of condition-based maintenance strategies. 
According to research, these strategies can be classified into two groups:

- maintenance according to the state with the parameter control, and

- maintenance according to the state with the confidence level control.

Maintenance according to the state with the parameters control, provides continuous or periodic control and measurement of technical parameters by which the technical condition of components and/or systems are determined. Decision on maintenance activities shall be taken then, when the value of the controlled parameters reach the limit of usability or pre-critical level.

Maintenance according to the state with the confidence level control is to collect, process and analyze data on the reliability of components and/or systems and develop the necessary decisions on planned maintenance activities on the replacement or repair of the system component parts.

\section{The formation of maintenance program}

Under the maintenance program here it will involve document ally created set to of methods adapted and the maintenance mode of components and / or systems, which provides the given management of technical condition and reliability in the given conditions of the exploitation process.

Maintenance program of an integral part and/or the system must be aimed at securing more efficiency of the integral part and/or systems with optimal costs.

The formation of maintenance program may be based on a rational combination of condition base maintenance with the traditional preventive maintenance.

Due to high complexity of technical system in power plant, this paper refers to the formation of the maintenance program at the plant constituent parts level (eg turbo group department with related equipment with the related equipment) although this can be worked also at the level of system component parts sub-assemblies.

The complex of the research program on maintenance of the components formation and / or system should, in principle, comprised three stages (the algorithm in Figure 1):

- the program variants formation of the first level

- the program variants formation of the second level

- assessment of the selection effectiveness of the maintenance program variants

If the termination part of the system does not affect the reliability of the system in operation, then with and failure intensity it is performed a comparison of secondary costs for corrective and preventive replacement, and in the event that these costs are the same, an integral part of the system is maintained according to the state with the level of confidence control.

If the costs of corrective maintenance are greater than the costs of preventive maintenance, it is applied the maintenance to state with the parameters control.

In the case the cancellation intensity is approximately constant, it is applied the maintenance the state of confidence level control.

In the event that failure of the system parts affects the reliability of the system in operation, it will be with the increase in the intensity of the failure used to maintain the state of control parameters, and it will be, at not growing cancellation intensity, applied the maintenance to the state to the level of reliability control. 
Assessment of the integral parts cancellation impact to the reliability system at work is done by comparing the probability of one of the possible system states occurrence with the corresponding permissible values given by the manufacturer. In doing so, there are used the methods of mathematical statistics and the intensity of failure is analyzed. To form failure intensity diagrams, it is necessary to process statistical data by the system component parts failures in the process of technical exploitation for less than 2-3 years.

Analysis of failure-free operation of system components can be made by unknown sequence:

- The failure intensity diagram forming

- According to the character changes of failure intensity it is deduced the assumption law of the failure distribution,

- Hypothesis Verification of the failure distribution law according to the criteria of Pearson and the like.

According to the results of modeling it can be determined:

- Frequency of entering the exploitation process individual state,

- Coefficient of component part land utilization and / or system as intended,

- Specific downtime due to maintenance,

- Average system recovery time,

- Specific cost of component part and / or system maintenance.

The impact of the system structural - exploitation properties on the effectiveness of the different maintenance strategies application, and thus the effectiveness of the maintenance program in its entirety, is to compulsory analyzed through changes of the reliability and maintenance costs.

The annual economic effect of the program components and / or system maintenance introduction, can arise from:

- exploitation costs for maintenance reduce,

- the components and / or system effectiveness increasing,

- the spare parts for replacement and oth. amount reduces.

\section{Spare parts saving by introducing of maintenance program}

Research conducted in our Thermal Power Plant, show that the probability of operation without components and / or system failure of, which are subject to random field firings, can describe the exponential and Weibull distribution for period of a work when the failure intensity is constant or increasing. For failures due to aging (gradual layoffs) work without failure probability can be described normal, lognormal, by Erlang and Weibull distribution for the period of work when failure intensity grows.

Based on these studies it can be made a maintenance program base for one technical system of certain type or the more common system in a working relationship by also the necessary replacement of spare parts schedule.

Using the new maintenance program as opposed to the base maintenance program involves the use of significant maintenance strategy according to the state, resulting in reduction of spare parts quantity. 
For the amount of "saving" constituents and - of this type, which are maintained according to the state with parameters control.

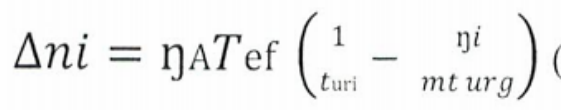

It can be achieved the economic

effect

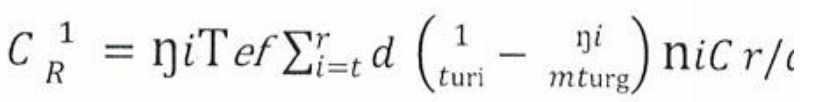

where:

$\eta_{A}$ efficiency coefficient of the system integral parts before the introduction of the maintenance program (at the base of maintenance program)

$\eta_{B}-$ coefficient efficiency coefficient of the system integral part after the introduction of the maintenance program,

Tef-the annual number of hours (Tef $=8760 \mathrm{~h})$

$\mathrm{r}_{\mathrm{d}^{-}}$the amount of system components parts which are maintained by the state-controlled parameters,

$t_{\text {uri- }}$ mean operation time between failures for the $\mathrm{i}$ - the constitual part in hours,

m- performance coefficient reduction of I - the constitual part of the system when his parameter reaches the limit of wear,

$t_{\text {urg }}-$ mean operation time in maintain by state in hours,

$\eta_{i^{-}}$coefficient ration of system integral part utilization after and before maintain program introduction $\left(\eta_{i}=\eta_{B} / \eta_{A}\right)$,

$n_{i}-$ the spare parts quantity of $i-$ th type in one system,

\section{type.}




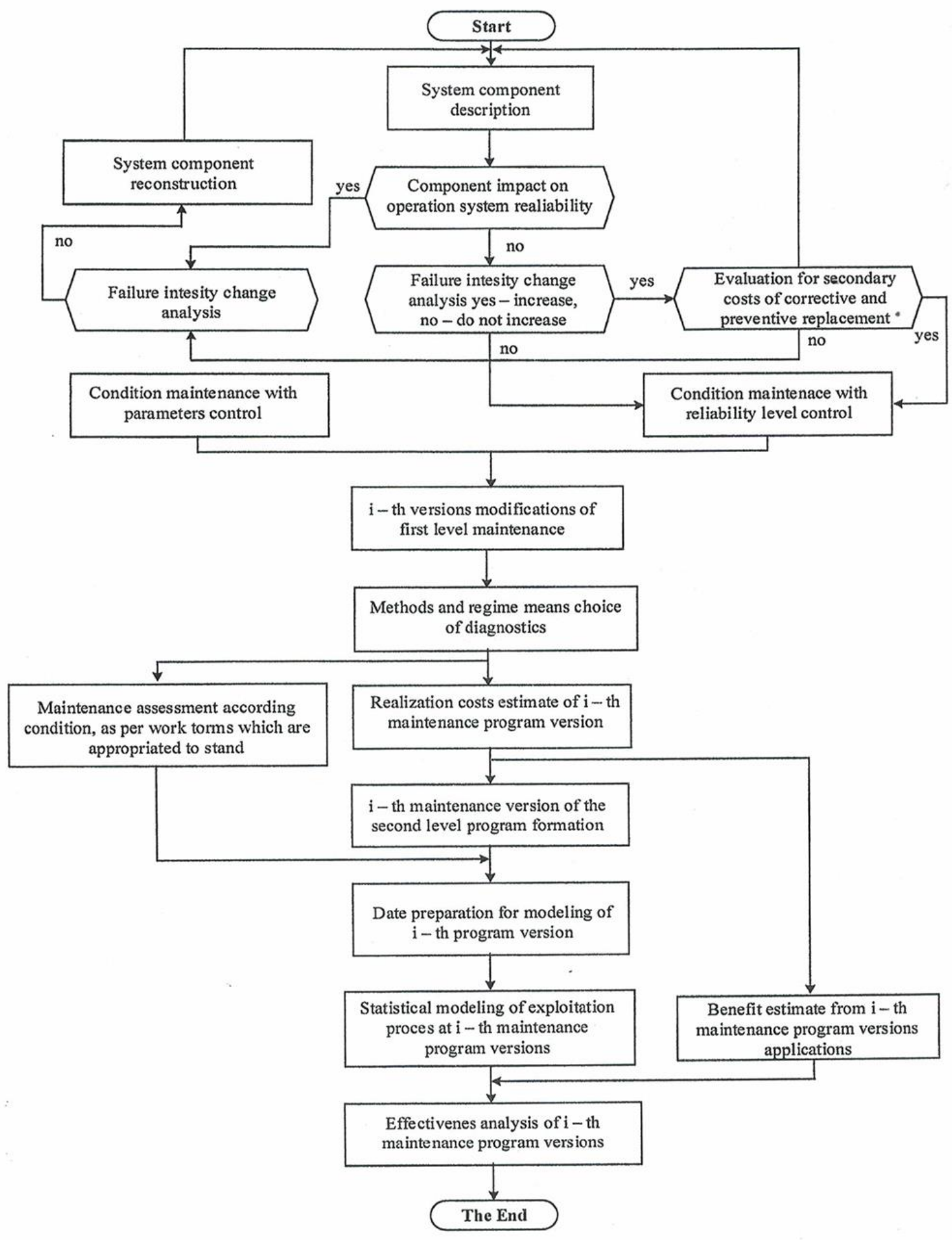

Figure 1 Program formation Algorithm of condition-based maintenance 
For the system integral paers maintained by the reliability level control, it is obtained an annual effect.

$$
C_{r}^{2}=\eta \mathrm{A} T \operatorname{ef} \sum_{i=1}^{n \mathrm{p}}\left(\begin{array}{c}
1 \\
t \text { uri }
\end{array}-\underset{t \text { ur } 2}{\eta i}\right) n \mathrm{C} C r / c
$$

where:

$\mathrm{n}_{\mathrm{p}}$ - the spare parts quantity maintained by the reliability level control.

Expressing mean operation time $\left(\mathrm{t}_{\mathrm{ur}}\right)$ by the parameters of the exponential, normal, log - normal, Erlang and Weibull laws, and incorporating them into (2) and (3), we get total saving of spare parts introducing maintenance programs

Where it is:

$\mathrm{k}, 1$ - the quantity of spare parts that are held according to the state of the confidence level control and parameters control, which are normal and log - normal probability distribution without failure operation.

$\mathrm{n}$ - the quantity of space parts that are held according to the state of the confidence level control that the have an exponential distribution with parameter operation without failure $\lambda_{\mathrm{i}}$,

ef - the quantity of spare parts that are held according to the state of the confidence level control and parameters control, which have Erlang probability distribution without failure work with $\mathrm{k}_{\mathrm{e}}$ and $\lambda_{\mathrm{e}}$,

$p, q$ - the quantity of spare parts that are held according to the state of the confidence level control and parameters control, which have Weibull probability distribution without failure work with parameters $\beta$ and $\eta$,

$$
\mathrm{t}_{\text {'urg }} \text { - expectation mean operation }
$$

time for normal and $\log -$ normal distribution,
$\Gamma$ - gamma function.

\section{The maintenance program formation for the turbine plant department}

Several interdependent technical systems pertain to the composition department of turbine installations and they are:

-steam turbine with lubrication systems, control oil, steam sealing, reinforcement of pipelines and measuring and control equipment,

-generator systems with sealing oil, water cooling of the stator, gas cooling generator rotor and measuring and control equipment,

-the base condensate line with a condenser, condensate pumps, low-pressure heaters, accompanying armature, pipelines and measuring and control equipment,

-the supply line with the supply tank, a feed pump, high - pressure heaters, piping, valves and $\mathrm{m}$ ensuring and control equipment.

Analysis of failure-free components operation of (subsystems) turbo generator plant (system) can be done on the basis of statistical data, obtained during the operation. Purpose of the statistics it to discover the law of work distribution to all subsystem's failure. By breaking the above subsystems in to its component parts, it also can be made failure-free operation analysis of all subsystem component parts. 


$$
\begin{aligned}
& C r=\eta A T e f\left(\sum_{i=1}^{k}\left(\frac{1}{\text { turi }}-\frac{\eta{ }^{i}}{\text { turi } i}\right) n i C \mathrm{r} / \mathrm{d}+\sum_{i=1}^{1}+\left(\frac{1}{\text { turi }}-\frac{\eta \mathrm{j} i}{\text { mt urg }}\right) n i C \mathrm{r} / \mathrm{d}+\sum_{i=1}^{f}\left(\begin{array}{c}
1 \\
\text { turi }
\end{array}-\right.\right. \\
& \left.\underset{m \frac{k e}{\lambda e}}{n}\right) n i C r / d+\sum_{i=1}^{p}\left[\frac{1}{t \text { uri }}-\frac{\eta]}{\left(\frac{1}{\eta}\right)^{1} / \beta \Gamma\left(1+\frac{1}{\beta}\right)}\right] n i C r / d+\sum_{i=1}^{n}\left(\frac{1}{\text { turi }}-\eta j i \lambda i\right) n i C r / d+\sum_{i=1}^{e}\left(\begin{array}{c}
1 \\
\text { turi }
\end{array}-\right. \\
& \left.\left.\frac{\eta \eta i}{\frac{k e}{\lambda e}}\right) n i C \mathrm{r} / \mathrm{d}+\sum_{i=1}^{q} \quad\left[\frac{1}{\text { turi }}-\frac{\eta{ }^{2}}{m\left(\frac{1}{\eta}\right)^{1} / \beta \Gamma\left(1+\frac{1}{\beta}\right)}\right] \text { niCr } / \mathrm{d}\right)
\end{aligned}
$$

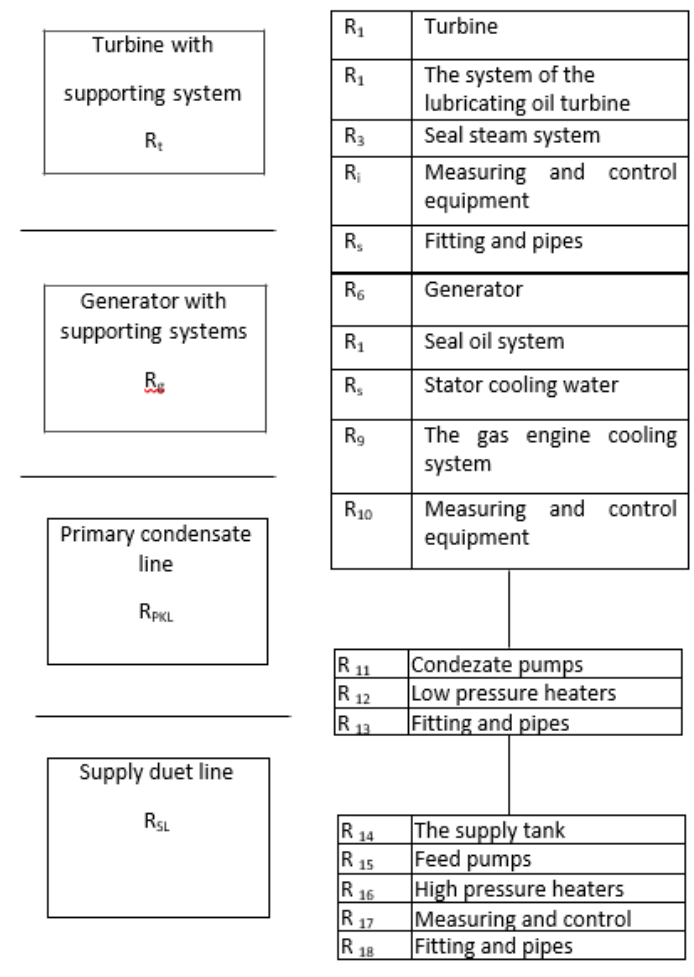

Figure 2. Scheme of the turbo generator plant device

The total reliability of the turbo generator plant $\mathrm{R}_{\mathrm{TG}}$ can be expressed by the equation:

\section{$\mathrm{R}_{\mathrm{TG}}=\mathrm{R}_{\mathrm{T}} \mathrm{R}_{\mathrm{G}} \mathrm{R}_{\mathrm{PKL}} \mathrm{R}_{\mathrm{SL}}$}

The resulting confirmation hypothesis of conformity with the statistical distribution with the theoretical enable the parameters determination of work distribution without failure, primarily drawing of conclusions about the character of the failure intensity change.
When forming a turbo generator plant variant maintenance program, it has gone from the situation that the cost of corrective and preventive maintenance (direct and indirect) is always greater than the cost of preventive and condition-based maintenance.

The system turbo generator components failure free operation analysis results, as well as propose miniatous variants are given in Table 1.

From Table 1. it is shown that out of 13 considered turbo generator plant integral parts, 1 are proposed form implementation of condition-based maintenance.

Performed analysis and selection of maintenance strategies for each component separately, allow the maintenance program formation (standard).

The established version effectiveness of the maintenance program assessment was carried out by comparison with their basic indicators of effectiveness (for corrective and preventive maintenance). In doing so, they obtained the following results:

- operational readiness of the turbo generator system is increased for 6.9-8.1\%,

- turbo generator plant reliability is increased to $4-8.5 \%$,

- specific maintenance costs (direct and indirect) were reduced by $14-$ $21 \%$, 
- annual economic impact of the maintenance program application to the state is $(18-22) * 10^{6} \mathrm{din}$.

These results are related also to developed maintenance programs for the component parts of certain turbo generator subsystems.

The impact of maintenance program established varieties number (implied the system constituent part percentage) on the reliability of turbo generator plant technical system is shown in Figure 3. At that, relative field of reliability increase is observed that has reached the current level of the selected maintenance program (40\% of all implied technical turbo generator systems). The plants readiness change from time is given in Figure 4. 


\begin{tabular}{|c|c|c|c|c|}
\hline $\begin{array}{l}\text { Component } \\
\text { part } \\
\text { position }\end{array}$ & $\begin{array}{l}\text { Title of turbo generator } \\
\text { plant component part }\end{array}$ & $\begin{array}{l}\text { Distribution law of } \\
\text { failure free } \\
\text { operation and its } \\
\text { parameters }\end{array}$ & $\begin{array}{l}\text { Change } \\
\text { character } \\
\text { of failure } \\
\text { intensity }\end{array}$ & $\begin{array}{l}\text { The propose application } \\
\text { maintenance strategy }\end{array}$ \\
\hline 1 & Condensate pumps & $\begin{array}{l}\text { Exponential } \\
\lambda=204 * 10^{-6}\end{array}$ & $\approx$ const & OPS-KNP \\
\hline 2 & $\begin{array}{c}\text { Measuring and control } \\
\text { equipment }\end{array}$ & $\begin{array}{l}\text { Weibull } \mathrm{R}=\mathrm{e}^{-} \\
\left(\frac{1}{6294}\right) 1.95\end{array}$ & increase & OPS-KP \\
\hline 3 & Fittings and pipes & $\begin{array}{l}\text { Weibull } \mathrm{R}=\mathrm{e}^{-} \\
\left(\frac{1}{5893}\right) 1.68\end{array}$ & $\approx$ const & $\begin{array}{l}\text { OPS-KNP } \\
\text { OPS-KP }\end{array}$ \\
\hline 4 & Turbine & $\begin{array}{c}\text { Normal } \\
m=9864, \sigma=3869\end{array}$ & increase & OPS-KP \\
\hline 5 & $\begin{array}{l}\text { The system of the } \\
\text { lubricating oil }\end{array}$ & $\begin{array}{c}\text { Normal } \\
m=8434, \sigma=3904\end{array}$ & increase & $\mathrm{PO}$ \\
\hline 6 & Feed pumps & $\begin{array}{l}\text { Exponential } \\
\lambda=1.86^{*} 10^{-6}\end{array}$ & $\approx$ const & PO \\
\hline 7 & Generator & $\begin{array}{c}\text { Erlang II order } \\
\lambda=4.15 * 10^{-6}\end{array}$ & $\approx$ const & OPS-KNP \\
\hline 8 & Stator cooling water & $\begin{array}{c}\text { Normal } \\
m=7647, \sigma=4098\end{array}$ & increase & OPS-KNP \\
\hline 9 & $\begin{array}{c}\text { The gas engine cooling } \\
\text { system }\end{array}$ & $\begin{array}{c}\text { Normal } m=8868 \\
\sigma=3338\end{array}$ & increase & OPS-KNP \\
\hline 10 & Low pressure haters & $\begin{array}{l}\text { Weibull } \mathrm{R}=\mathrm{e}^{-} \\
\left(\frac{1}{4682}\right) 1.95\end{array}$ & increase & OPS-KP \\
\hline 11 & High pressure heaters & $\begin{array}{l}\text { Weibull } \mathrm{R}=\mathrm{e}^{-} \\
\left(\frac{1}{4468}\right) 1.95\end{array}$ & increase & OPS-KP \\
\hline 12 & Seal steam system & $\begin{array}{c}\text { Erlang II order } \\
\lambda=2,22 * 10^{-6}\end{array}$ & increase & OPS-KNP \\
\hline 13 & The supply tank & $\begin{array}{l}\text { Weibull } \mathrm{R}=\mathrm{e}^{-} \\
\left(\frac{1}{45682}\right) 1.55\end{array}$ & & $\mathrm{PO}$ \\
\hline
\end{tabular}

Table 1The result of the analysis and proposed option strategies for turbo generator plant maintaining components.

PO- preventive maintenance at a constant sustainability

OPS-KP - Condition base maintenance with parameters control

OPS-KNP - Maintenance according to state with reliability level control 


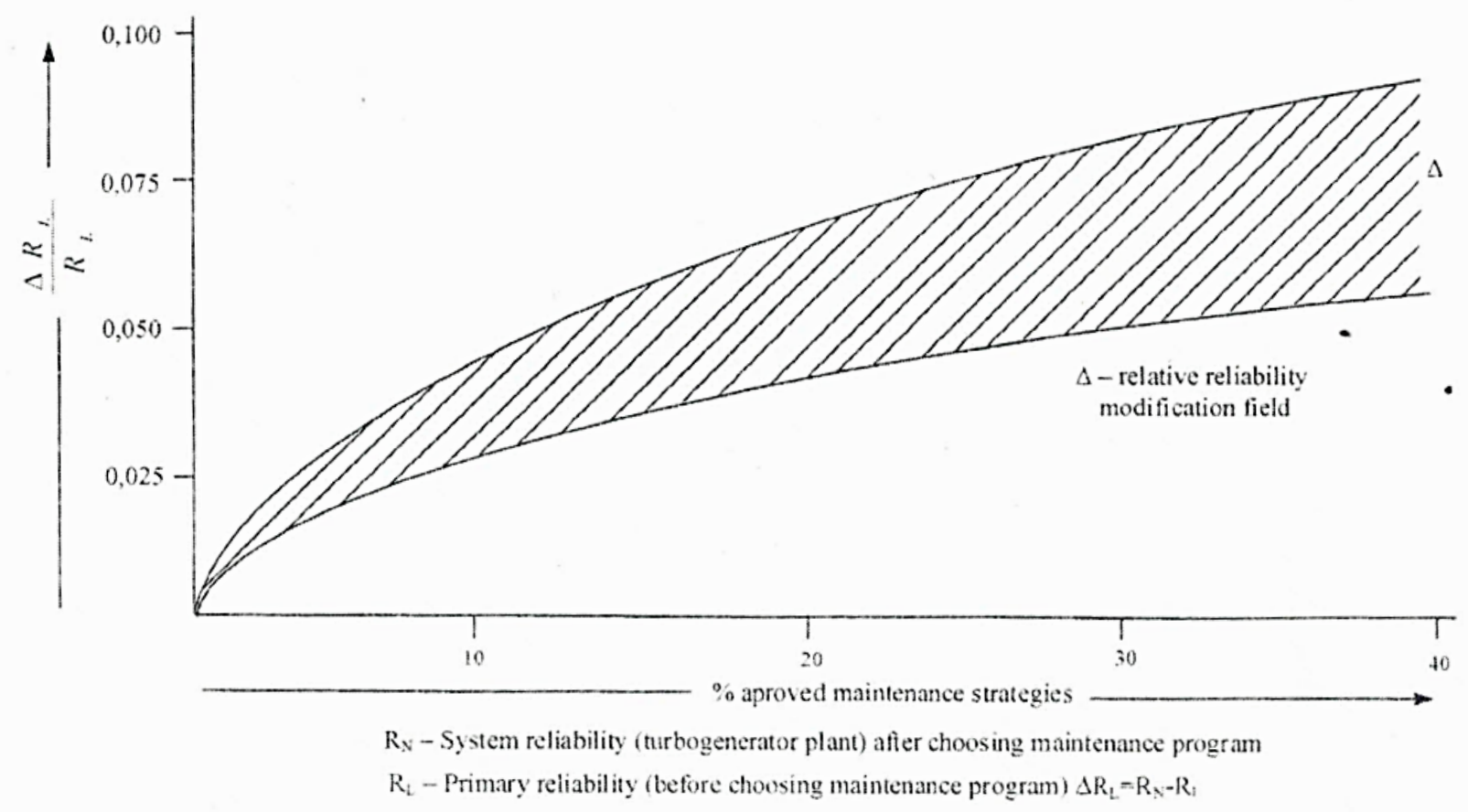

Figure 3. The impact of the formation of the maintenance program turbo generator plants

The formation period $t_{k}$ (Figure 4) can be explained by the fact that earlier the replacement of spare parts was carried out without sufficient use of reserves usability and mainly the parts were imported. Today it is used by local spare parts whose base (designed) reliability is slightly lower than the reliability of imported parts.

With the introduction of specific programs to maintenance turbo generator plant and the specific cost of spare parts and materials were reduced (Figure 5).

Some benefits are obtained by the introduction of the maintenance program gave in Figure 6.

This paper deal with a group of turbo generator plant constituents. For comprehensive resolution of system maintenance, it is to be performed processing, after the methodology of all components which during operation are getting older. 


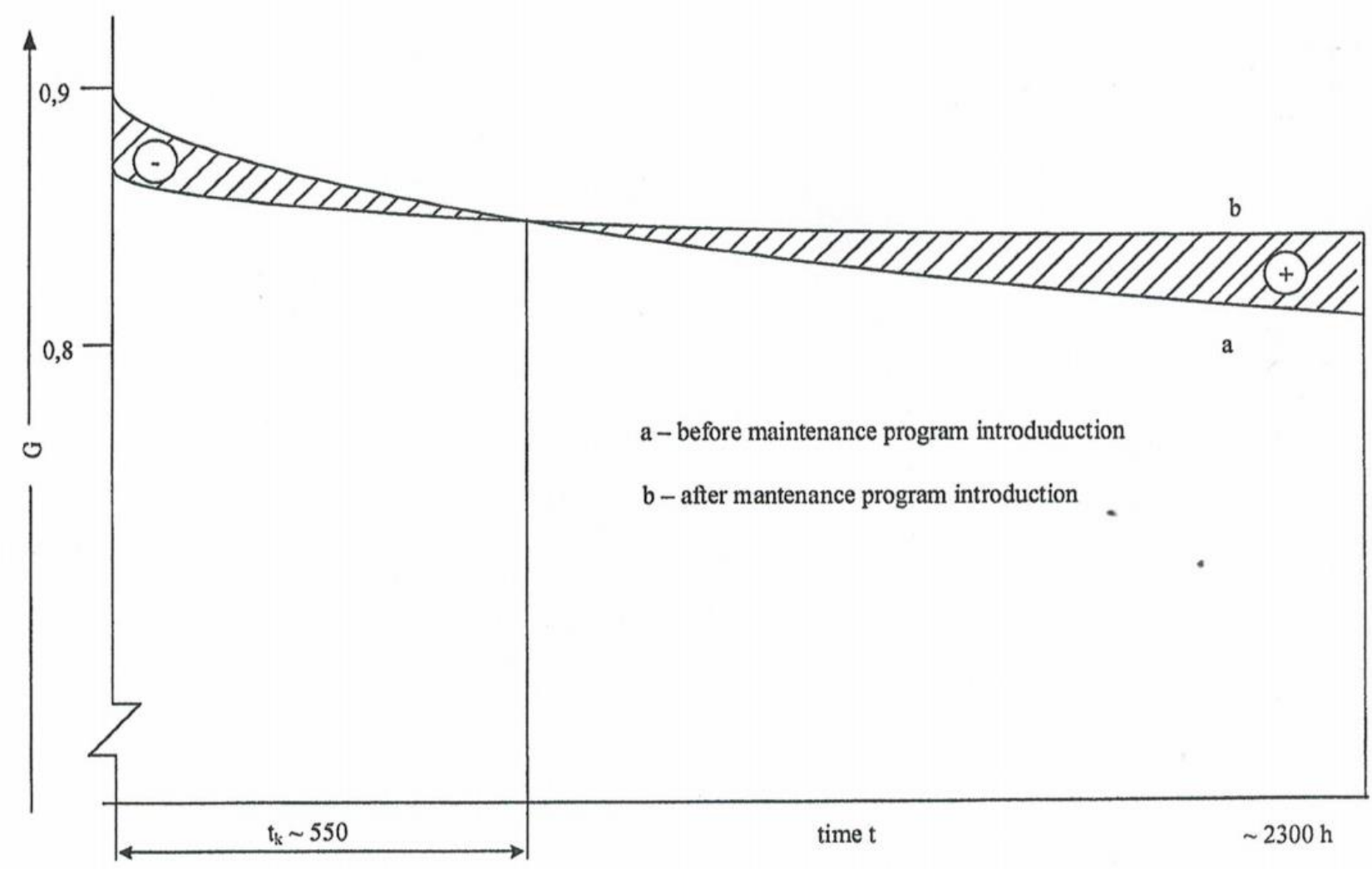

Figure 4. Change of turbo generator plant readiness

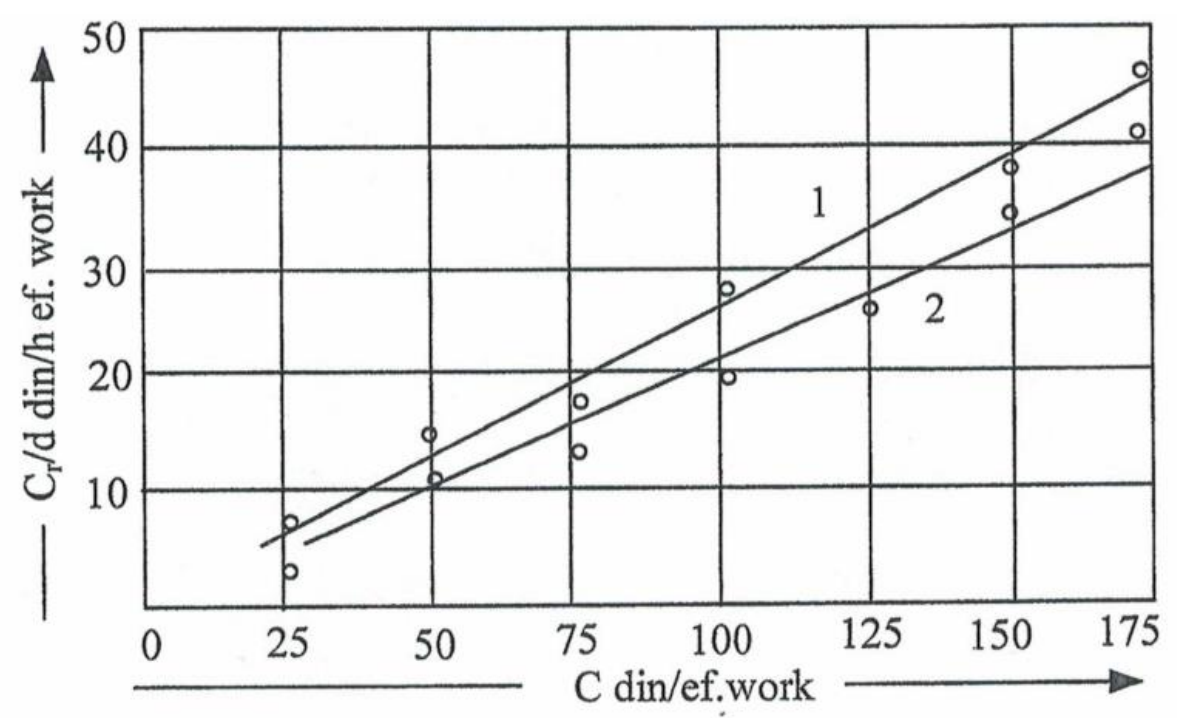

1- preventive maintenance program $\mathrm{C}$ - specific maintenance costs 2 - condition maintenance program $\mathrm{Cr} / \mathrm{d}$ - specific costs of spare parts

Figure 5. The specific cost of spare parts and materials depending on the specific turbo generator plant maintenance costs 
(JPMNT) Journal of Process Management - New Technologies, International

Vol. 8, No4, 2020.

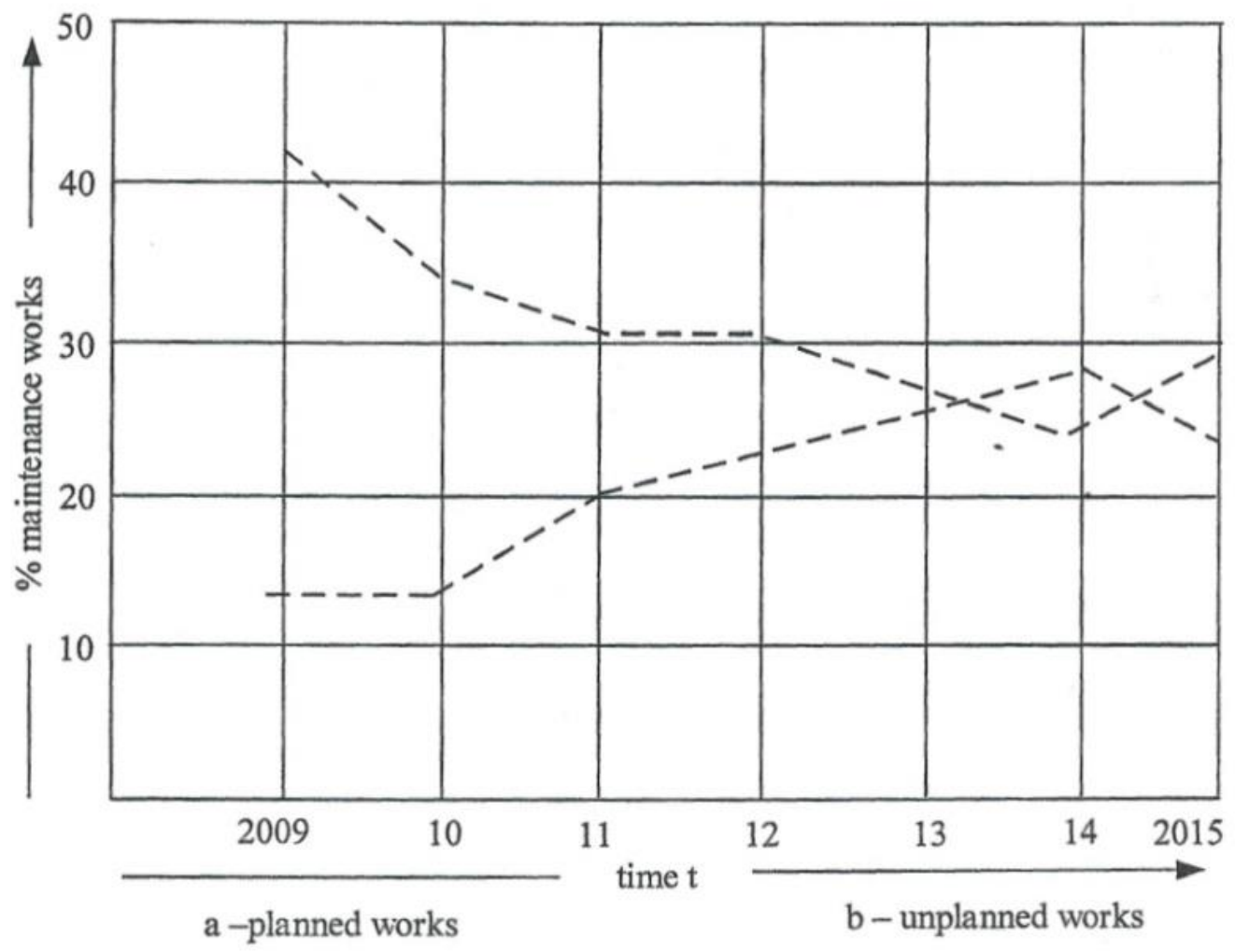

a)

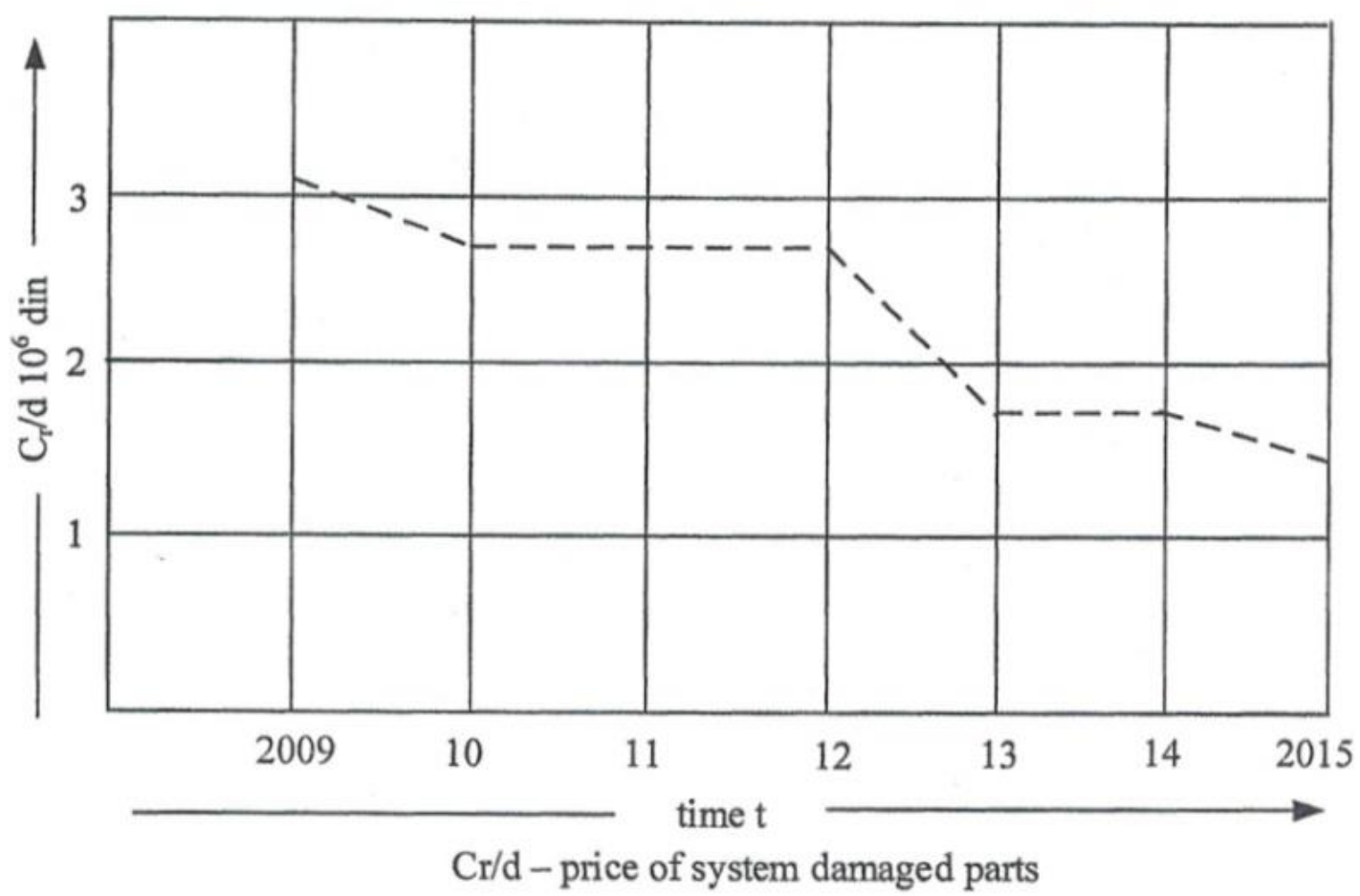

b) 


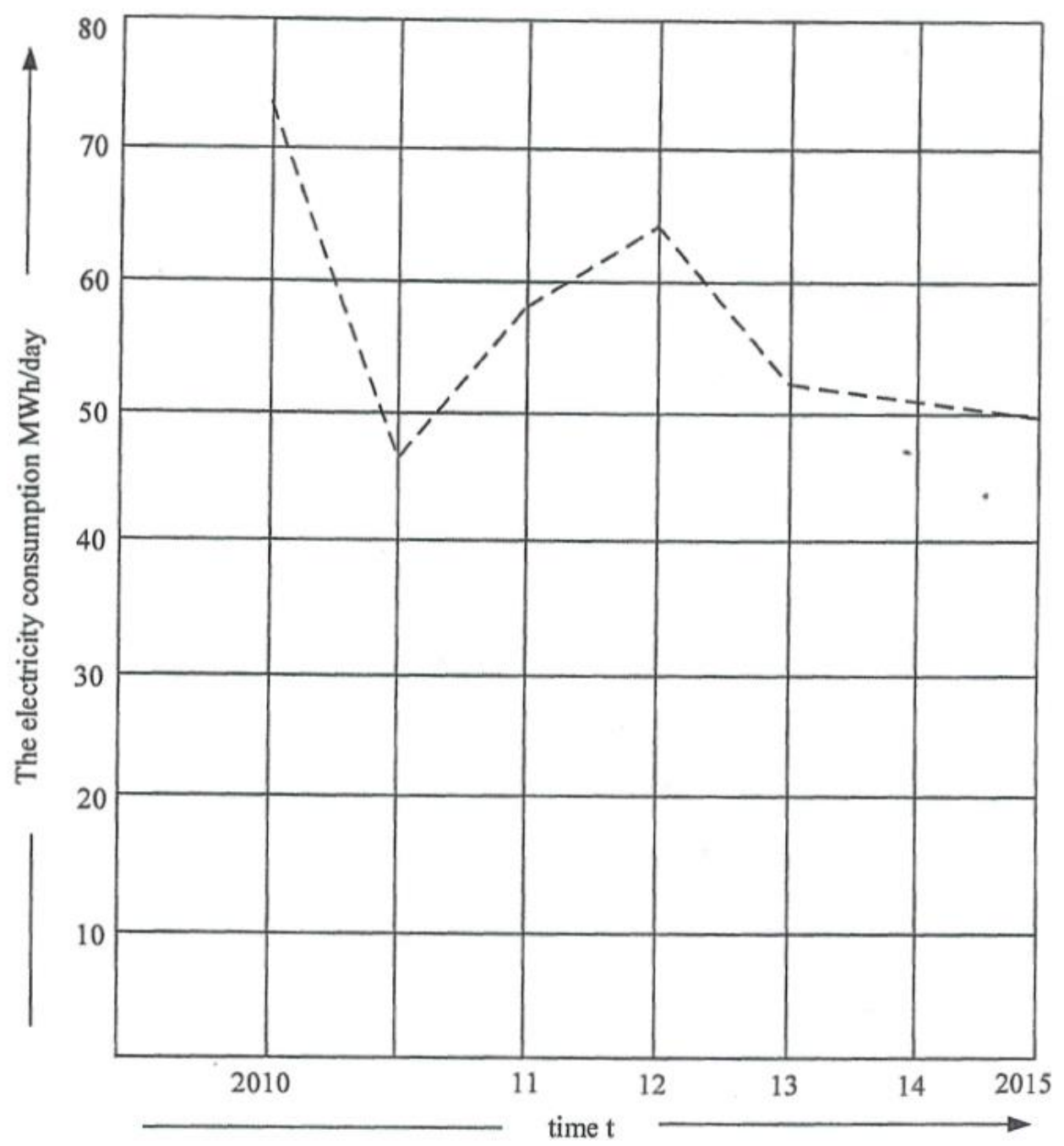

c)

Figure 6. a), b), c) The benefit of introducing program of turbo generator facilities in thermal power plant optimal maintenance 


\section{Conclusion}

The maintenance

program implementation can:

- increase the technical systems effectiveness,

- reduce total maintenance cost,

- improve the organization of production and maintenance,

- reduce electricity consumption,

- increase the level of work motivation,

- raise the level of planned activities in the maintenance and other.

\section{References}

1. Adamović, Ž., Ilić, B., Nauka o održavanju tehničkih sistema, Srpski akademski centar, Novi Sad, 2013.

2. Adamović, Ž., Ilić, B., Josimović, Lj., Savremeni izvori energije, Društvo za tehničku dijagnostiku Srbije, Beograd, 2019.

3. Vulović, S., Integrisani model održavanja zasnovan na uspostavljanju zakonitosti promene mehaničkih vibracija i njihov uticaj na prognostiku stanja rotacionih mašina (doktorska disertacija (Univerzitet u Novim Sadu), Novi Sad, 2017.

4. Adamović, Ž., Ivić, M., Vuković, V., Metodologija i tehnologija izrade naučnih radova, Univerzitet PIM, Banja Luka, 2017. 